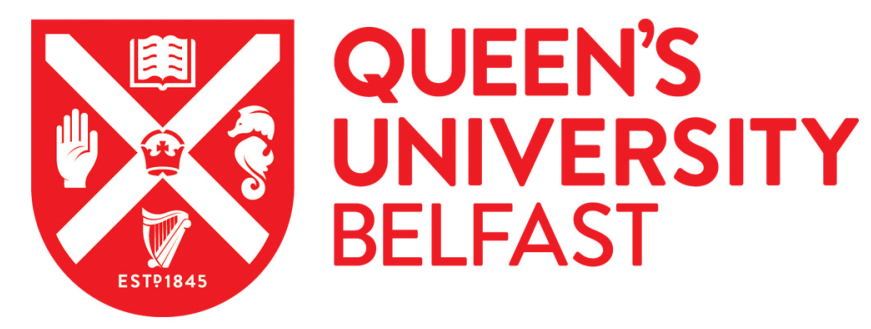

\title{
The health status and health service needs of primary caregivers of cancer survivors: a mixed methods approach
}

Santin, O., Treanor, C., Mills, M., \& Donnelly, M. (2014). The health status and health service needs of primary caregivers of cancer survivors: a mixed methods approach. European Journal of Cancer Care, 23(3), 333-339. https://doi.org/10.1111/ecc.12157

\section{Published in:}

European Journal of Cancer Care

\section{Document Version:}

Peer reviewed version

\section{Queen's University Belfast - Research Portal:}

Link to publication record in Queen's University Belfast Research Portal

\section{Publisher rights}

This is the peer reviewed version of the following article: European Journal of Cancer Care, which has been published in final form at http://doi.org/10.1111/ecc.12157 This article may be used for non-commercial purposes in accordance with Wiley Terms and Conditions for Self-Archiving $\odot 2013$ John Wiley \& Sons Ltd

\section{General rights}

Copyright for the publications made accessible via the Queen's University Belfast Research Portal is retained by the author(s) and / or other copyright owners and it is a condition of accessing these publications that users recognise and abide by the legal requirements associated with these rights.

Take down policy

The Research Portal is Queen's institutional repository that provides access to Queen's research output. Every effort has been made to ensure that content in the Research Portal does not infringe any person's rights, or applicable UK laws. If you discover content in the Research Portal that you believe breaches copyright or violates any law, please contact openaccess@qub.ac.uk. 
The health status and health service needs of primary caregivers of cancer survivors: a mixed methods approach

\section{Olinda Santin, Charlene Treanor, Moyra Mills and Michael Donnelly}

Corresponding author: Olinda Santin, School of Nursing and Midwifery, Queen's University Belfast, Medical Biology Centre, Block 97, Health Sciences, Belfast

Telephone: 028906333078 email: o.santin@qub.ac.uk

Charlene Treanor: Centre for Public Health and UKCRC Centre of Excellence for Public Health, Queen's University Belfast, School of Medicine, Dentistry and Biomedical Science, Institute of Clinical Sciences B, Royal Victoria Hospital, Grosvenor Road, Belfast. BT126BJ. C.treanor@qub.ac.uk

Moyra Mills: Northern Health and Social Care Trust. Cancer Services, Antrim Area Hospital, Bush Road, Antrim. BT41 2RL

Michael Donnelly: Centre for Public Health and UKCRC Centre of Excellence for Public Health, Queen's University Belfast, School of Medicine, Dentistry and Biomedical Science, Institute of Clinical Sciences B, Royal Victoria Hospital, Grosvenor Road, Belfast. BT126BJ. michael.donnelly@qub.ac.uk 


\section{Introduction}

The number of people living past their treatment for cancer is increasing exponentially with cancer survivors representing approximately 3.7\% of the American Population and 3\% of the UK population [1-2]. As the prevalence of cancer rises, there is increasing emphasis on the role of 'informal caregivers' and the impact of caring on health and wellbeing. However, research on informal caregivers has been slow to develop and studies have (a) focused on specific impacts of caring such as difficulties with coping or adjustment [4-5], (b) used instruments which have not been validated [6] and (c) concentrated on the acute survivorship stage [3]. No study has spanned the health status, health service use, satisfaction and unmet needs of caregivers and there is an absence of caregiver research at the remission stage of cancer [3].

Drawing mainly from research at the initial or advanced stages of cancer, over 200 problems associated with caring for someone with cancer have been identified including back and muscular pain, disturbed sleep and fatigue [7] and psychological difficulties such as intense worry and stress [8], depression [9-11], anxiety and cancer recurrence concerns. The problems and needs associated with informal caring may last for prolonged periods of time, even when a patient is 'free' of disease [12]. International cancer policy [13-15] has highlighted the need to monitor caregivers of cancer patients through all stages of the illness trajectory. The UK devolved governments are reviewing the merit of providing alternative methods of follow-up for cancer survivors. It is important that the health and wellbeing and service needs of informal caregivers are considered within these plans.

Methods

Ethical approval was granted by the Office of Research and Ethics Committee Northern Ireland. A mixed-methods approach was used to investigate the health and health care profile of informal caregivers. In Phase 1, semi-structured interviews were conducted with 24 professionals and cancer charity representatives (see Table 1) in the five Health and Social Care Provider Trusts in Northern Ireland (NI) to identify the care needs of cancer caregivers and current service receipt arrangements. A combination of purposive and snowball sampling techniques were used to recruit lead participants (see Table 1). Interviews were tape-recorded and transcribed verbatim. Respondent validation indicated that transcripts were an accurate account of the interview. In addition, the researcher completed a post-interview 
appraisal to aid the content analysis of transcripts. A coding framework was developed iteratively by two researchers reading, coding and discussing the interview texts.

In Phase 2, a population-based survey was conducted to assess the health and wellbeing of cancer survivors and their informal caregivers [16]. A total of 865 cancer survivors (2-20 or more years post-diagnosis) from 20 GP practices were identified via the NI Cancer Registry (NICR). Cancer survivors were mailed a questionnaire pack and in addition were asked to give a questionnaire to their nominated adult primary caregiver. The caregiver survey questionnaire comprised socio-demographic questions, SF-36 health status [17], two questions about health service use [18] and a question about satisfaction with services.

Statistical analysis

Domain and component summary scores were calculated to assess health status [17]. Values were imputed for missing data when at least $50 \%$ of questions in a given domain were answered. A mean score was calculated for each domain based on the total number of completed item responses. The mean score was multiplied by the total number of items within the relevant domain to impute scores and indicate how caregivers may have responded had the questionnaire been fully completed. An individual who left $>50 \%$ items in a domain unanswered was excluded from the analysis for that particular domain. Independent samples t-tests with the Bonferroni correction tested differences between survivors and caregivers on each SF-36 domain. Multiple linear regressions examined the relationship between health and wellbeing and caregiver characteristics. The non-parametric MannWhitney-U test was used to examine between-group differences in the non-normally distributed health service utilisation data.

Results

A number of key themes were identified including an absence of statutory or publicly-funded care, information needs, psychological concerns, financial strain and lack of involvement in decision-making.

Theme 1: Statutory health care provision for carers

According to professionals, carers of cancer survivors are affected negatively by the experience of cancer even when their relative is deemed to have been cured; and their needs are largely unmet. There is no formal or statutory service provision dedicated specifically to 
cancer caregivers. Current supports were described as 'ad hoc' and service receipt was dependent on a caregiver presenting to their GP. Caregivers were described as having limited involvement in follow-up consultation about cancer survivors and care professionals felt that carers did not receive adequate care provision.

"I mean it is a thing you think about (needs of caregivers) but it would be well down the list but we would be very aware of the implications this has for families..." (Lead Clinician)

\section{Theme 2: Information}

Caregivers were described as being ill-informed regarding the chances of recurrence and as often experiencing anxiety and fear that the cancer may have returned. Cancer professionals were concerned that this recurrence anxiety may develop into more serious psychological difficulties.

"Caregivers continually worry that the cancer will come back...every time there is an ache or a pain they think, is this it back?’' (Lead Nurse)

Spouses who become distressed when their partners struggle to cope with altered body image and with changes regarding their sexuality may have particular information needs. Professionals did not feel adequately skilled to deal with these complex issues.

Cancer may have financial implications for a family when a relative has to stop work and income is reduced. Caregivers too may have to leave their employment or reduce their working hours in order to provide care. Although professionals recognised implications of providing care for a cancer survivor, they noted that they did not discuss these issues with caregivers because they did not feel that they had the resources, skill and time to do so.

\section{"We know that it's an issue (finance) but it's way down the list". (Lead Clinician)}

\section{Theme 3: Psychological need}

According to professionals, cancer caregivers have unmet psychological needs particularly regarding stress and coping with the "burden” of providing physical care alongside worry about their relative's health. Yet, carers are asked infrequently about how they are coping and are given an opportunity only occasionally to raise concerns. Some carers may benefit from services such as self-management programmes in order to learn how they might improve their coping skills. 


\section{“Caregivers can feel pretty down, they don't talk about how it's impacting on them because it's all about the patient." (Charity Organisation Representative).}

\section{Theme 4: Lack of involvement in decision-making}

It was noted that there was little involvement of caregivers in health and social care decisionmaking and that caregivers needed practical support due to their role-change as a caregiver. Caregivers tend to feel excluded from discussions at appointments and to lack information regarding medical treatment of cancer as well as being unsure of the implications of living with a cancer diagnosis. According to professionals, ideally, carers and families should be informed and involved in decisions that affect them and to be supported to feel that they have some degree of control over the cancer experience.

'I think they can feel quite isolated and their emotional needs are not dealt with', (Lead Nurse)

In total, 98 caregiver dyads returned completed questionnaires. It was not possible to calculate a precise response rate as the request for a caregiver to participate was administered via each cancer survivor . The majority of caregivers were female (65\%) with an average age of 58 years and provided informal care to survivors of breast (32\%) or prostate cancer (24\%). Forty per cent provided care to survivors who had received their diagnosis between 7 and 20 years or more ago; $36 \%$ provided care to survivors one to three years post-diagnosis; and around $24 \%$ of survivors were four to six years post diagnosis. The majority of informal caregivers were spouses (80 \%). Over one quarter of caregivers (29\%) spent more than 22 hours per week providing care for cancer survivors. Direct caring tasks relating to mobility (16\%) and personal care (18\%) were not reported frequently. Most (82\%) cancer caregivers described their role in terms of 'keeping an eye out' and 'being there' for cancer survivors and accompanying survivors to activities and appointments (80\%).

Caregivers reported significantly better scores for physical function, physical role limitations and overall physical component summary score than survivors. No statistically significant differences were found for the other SF-36 domains or for number of illnesses (see Table 2).There were no significant differences in physical health and mental health summary component scores respectively or number of reported illnesses between cancer survivors and informal cancer caregivers (see Table 2). Regression analysis demonstrated that there was no relationship between caregiver characteristics and caregiver's physical health score (see 
Table 3). Unsurprisingly, there was a significant relationship between the number of illnesses reported by caregivers and their physical component score in the expected direction . There was a significant association between health service utilisation and caregiver mental health component summary score. Caregivers who reported poorer mental health summary scores used health services more frequently (see Table 3).

There were no significant differences between survivors and caregivers in the use of GPs, mental health professionals, allied-health professionals, district nurses, hospital in-patients or complementary medicine. Cancer caregivers reported significantly fewer visits to primary care professionals (other than GPs) and to out-patient appointments compared to survivors (see Table 4). Most caregivers (88\%) and survivors (90\%) were satisfied or very satisfied with services.

\section{Discussion}

The majority of caregivers were female (65\%) and spouses (80\%) of cancer survivors similar to the profile of informal carers reported in other caregiver studies [19, 7, 20]. Over one quarter (29\%) reported spending 22 hours or more per week care giving. Caregiving tended to be socially supportive in nature such as 'keeping an eye out' (82\%) and accompanying relatives to activities and appointments (80\%). A small proportion of cancer caregivers reported providing personal care such as feeding or bathing; and these individuals were more likely to report spending 22 or more hours per week caring. The high proportion of reported 'social activities' may be a normal part of spousal relationships and may be reported irrespective of whether or not a cancer diagnosis was present.

This study was conducted as part of a larger health and wellbeing study which found that cancer survivors reported poorer health and wellbeing compared to a matched age and gender General Practice population [16]. Cancer caregivers reported significantly better physical health than cancer survivors and these differences may be considered to be clinically meaningful. Compared to UK general population norms, unsurprisingly, cancer caregivers performed substantially lower on each health domain. Differences of two or more points for role functioning and 3 or more points for social functioning, bodily pain, general health, vitality, mental health and 4 or more points for emotional functioning are considered clinically meaningful [21-22]. It may be argued that a general population-cancer caregiver comparison is not a fair or like-with-like comparison. However, compared to caregivers of multiple sclerosis patients [23] diabetes patients and stroke patients [24] cancer caregivers 
reported poorer physical health scores. This finding suggests that caregivers do not experience the same degree of poor physical health as survivors but they do experience more physical difficulties than the general population and other types of caregivers. Studies of the quality of life of caregivers of cancer survivors are scarce [5].

There were no significant differences in scores between cancer survivors and caregivers in terms of emotional role limitations, vitality, mental health perception, pain, social functioning and mental component score. This result may suggest that cancer may have a similar psychological impact on caregivers as it has on survivors. Compared to UK age-matched population norms, cancer caregivers in this study reported substantially lower, perhaps clinically lower scores on each domain of the SF-36 [25]. Furthermore, caregivers in this study reported lower scores than caregivers of terminally ill patients [26] and US cancer caregivers 2 months, 2 years and 5 years post diagnosis of treatment [27]. Caregivers of cancer survivors may fair less well due to fear of the future or due to a lack of specific, available support.

Regression analyses did not indicate an association between physical health or mental health component scores and sex, age and time since diagnosis. In contrast, research from the treatment and advanced stages of cancer indicates that females and younger patients report poorer outcomes [28-29]. Health impacts appear to be less differentiated during the survivorship phase.

Cancer continues to have an impact on the health and wellbeing of caregivers long after treatment has ended. For example, the results indicated that caregivers reported poorer health compared to age matched UK norms. It may be the case that only cancer caregivers who provided care for cancer survivors with complex needs responded to this study. The subjective nature of the data collection measures may have led to an over- or underestimation of health and wellbeing [30]; the use of objective measures such as prescription data or referrals to health professionals were not available.

Cancer care professionals reported that caregivers' needs were largely unmet. In particular, there appeared to be a need for information regarding cancer recurrence, body image and sexuality, finance, medical treatment, medications and the implications of living with a cancer diagnosis. Cancer caregivers do not tend to be afforded an opportunity to voice their concerns or issues. The needs identified here concur with a needs assessment of an Australian caregiver population [31]. Providing appropriate information and providing an opportunity 
for caregivers to discuss how they are coping may improve their physical and mental wellbeing. Cancer caregivers visited their GP, on average, 3 times per year and therefore primary care may be an appropriate avenue for the delivery of information and support. The care-giver reported high level of satisfaction with services conflicts with the finding that caregiver needs reported by professional staff were largely unmet. This lack of agreement may be due, for example, to the questionable validity of questionnaire measures of satisfaction, the reluctance among people, particularly older people, to complain and differences between professionals and lay people regarding their respective frames of reference for assessing the quality of a service.

The results of this study suggest that the cancer experience has a detrimental effect on the health and wellbeing of cancer caregivers after treatment has ended. Currently, service planners and providers are considering the reconfiguration of cancer follow-up services. It is important that the needs of caregivers are considered within these plans. A holistic model of community and primary care-based follow-up with links to secondary care should include the health and wellbeing of caregivers, particularly information provision, health education and well-being programmes. Future research should consider the development of psychosocial interventions for cancer caregivers and examine their effectiveness in the post treatment phase of disease.

Acknowledgements

This study was sponsored by Macmillan Cancer Support. The Northern Ireland Cancer Registry is funded by the Public Health Agency.

Conflict of Interest: None 
References

1]Horner, M. Ries, L. Krapcho, M. Neyman, N. Aminou, R. Howlader, N. SEER Cancer Statistics Review 1975-2006. National Cancer Institute. Bethesda MD. 2006

2] Maddams, J. Moller, H. Brewster, D. Gavin, A. Steward, J. Elliot, J. Utley, M. Cancer prevalence in the United Kingdom: estimates for 2008. Br J Cancer 2009; 101:541-547, DOI: 10.1038/sj.bjc.6605148

3) Kim, Y. Given, B. Quality of life of family caregivers of cancer survivors. Cancer 2008; 112:2556-2568, DOI:10.1002/cncer.23449

4] Northouse, L. Modd, D. Templin, T. Mellon, S. George, T. Couples' patterns of adjustment to colon cancer. Soc Sci Med 2000; 50: 271-284; DOI:10.1016/502779536990028-1-6

5]Mellon, S. Northouse, L. Weiss, L. A population based study of the Quality of Life of cancer survivors and their family caregivers. Cancer Nurs; 2006: 29: 120-31.

6] Minaya, P. Baumstarck, K. Berbis, J. Goncalves, A. Barlesi, F. Michel, G. Salas, S. Chinot, O. Grob, JJ, Seitz, J. Bladou, F. Clement, A. Mancini, J. Simeoni, M. Auquier, P. Eur J Cancer Care 2012, 48.904-911; 10.1016/j.bbr.2011.03.031

7] Stenberg, U. Ruland, C. Miaskowski, C. Review of the literature on the effects of caring for a patient with cancer. Psycho-Oncology 2010, 19:1013-1025;d01:10.1002/pom.1670

8]Hagedoorn, M.Buunk, B. Kuijer, R. Wobbes, T. Sanderman, R. Couples dealing with cancer: role and gender difference regarding psychological distress and quality of life. Psycho-oncology, 17:63-74; DOI:10.1002/1099-1611

9] Hodges, L. Humphris, G. Macfarlane, G. A meta-analytic investigation of the relationship between the psychological distress of cancer patients and their carers. Soc Sci Med 2005, 60:1-12. DOI:10.10.1016/j.socscimed.2004.04.018

10] Rhee, Y. Yun, Y. Park, S. Shin, D. Lee, K. Yoo, H. Kim, J. Kim, S. Lee, R. Lee, Y. Kim, $\mathrm{N}$. Depression in family caregivers of cancer patients: the feeling of burden as a predictor of depression. Journal of Clinical Oncology 2008; 36, 5890-5. DOI:10:10.1200/jc.2007.15.3957 
11] Campbell, S. Sanson-Fisher, R. Taylor-Brown, J. Hayward, L. Wang, S. Turner, D. The cancer support person unmet needs survey. Cancer 2009; 115:33519.DOI:10.1002/CNCR.24386

12] Hodgkinson, K. Butow, P. Hobbs, K. Hunt, G. Lo, S. Wain, G. Assessing unmet supportive care needs in partners of cancer survivors: the development and evaluation of the Cancer Survivors Partners Unmet Need Measure (CaPSUN). Psycho-oncology 2007.doi:10.1002/pon.1138

13] US Department of Health and Human Services. National Family Caregiver Support Program 2003

14] Cancer Reform Strategy. Department of Health England 2007.

15] Australian Government. The National Palliative Care Programme. Department of Health and Ageing 2008.

16] Santin, O. Mills, M. Treanor, C. Donnelly, M. A comparative analysis of the health and well-being of cancer survivors to the general population. Support Care Cancer 2012, In Press; DOI: 10.1007/s005/s00520-011-1372-9

17]Ware, JE. Kosinski, M. Keller, SD. Physical and mental health summary scales: a user's manual Boston: The Health Institute, New England Medical Centre, 1994.

18] Elliott, J. Fallows, A. Staetsky, L. Smith, P. Foster, C. Maher, E. Corner, J. The health and well-being of cancer survivors in the $\mathrm{UK}$ : findings from a population-based survey. $\mathrm{Br} \mathrm{J}$ Cancer 2011; 105, 11-20; DOI: 10.1038/bjc.2011.418

19] Van Ryn, M. Sanders, S. Kahn, K. Van Houtven, C. Griffin, J. Martin, M. Atienza, A. Phelan, S. Finstad, D. Rowland, J. Psychooncology 2011. 20.44-52.DOI: 10.1002/pon.1703

20] Donnelly, M. Anderson, L. Murray, L. Oesophageal cancer: caregiver mental health and strain. Psycho-Oncology 2008; 17:1196-1201. DOI:10.1002/PON.1337

21] Ware JE, Kosinski MA. SF-36® physical and mental health summary scales: a manual for users of version 1. 2. Lincoln: QualityMetric Inc; 2001.

22]. Ware JE, Kosinski MA, Dewey JE. How to score version 2 of the SF-36 health survey. Lincoln: Quality Metric Inc.; 2000. 
23]Patti, F. Amato, M. Battaglia, M.Pitaro,M. Ruso, P. Solaro, C. Trojano, M. Caregiver quality of life in a multicenter Italian Study. Mult. Scler. J.20.44-52. DOI: $10.1177 / 1352458506070707$

24]Li, T. Lee, Y. Lin, C. Amidon, R. Quality of Life of Primary Caregivers of Elderly with Cerebrovascular Disease or Diabetes Hospitalised for Acute Care: Assessment of Wellbeing and Functioning Using the SF-36 Health Questionnaire. Qual Life Res 2004.13,10811088:DOI:10.1023/B:QUEW.0000031349.25124.D6

25] Jenkinson C, Layte R, Wright L, et al (1996) The UK SF-36: an analysis and interpretation manual. Oxford: Health Services Research Unit

26] Weitzner, M. Mc Millan, S. Jacobsen, P. Family Caregiver Quality of Life: Differences Between Curative and Palliative Cancer Treatment Settings. J Pain Symptom Manage 1999. 17.418-28.doi/10.1016/so885-39249900014-7

27] Kim,Y. Kashy, D. Spillers, R. Evans, T. Needs assessment of family caregivers of cancer survivors: three cohort comparisons. Psycho-oncology 2010.6, 573-582; DOI:10.1002/PON.1597

28] Daly, B. Douglas, S. Lipson, A. Foley, H. Needs of older caregivers of patients with advanced cancer. J Am Geriatric Soc 2009. 57:293-5; DOI:10.1111/J.15325415.2009.02516.X

29] Harding, R. Higginson, J. What is the best way to help caregivers in cancer in palliative care? A systematic literature review of interventions and their effectiveness. Palliative Med 2003; 17, 63-74

30] Van de Mortel, TF. Faking it: Social desirability response bias in self-report research. AJAN.25, 40-48.

31] Girgis, A. Lambert, S. Lacathelincus , C. (2010) The supportive care needs survey for partners and caregivers of cancer survivors: development and psychometric evaluation. Psycho-Oncology. 20, 387-393. 
Table 1 Occupational background of interviewees

\begin{tabular}{|l|l|}
\hline Number & Occupation \\
\hline 4 & Lead Clinician \\
\hline 7 & Cead Nurse \\
\hline 1 & Psychologist \\
\hline 1 & Social Worker \\
\hline 1 & Dietician \\
\hline 1 & Pharmacist \\
\hline 1 & Occupation Therapist \\
\hline 1 & Physiotherapist \\
\hline 3 & Not-for-profit organisation \\
\hline & GPysician) \\
\hline
\end{tabular}


Table 2: SF-36 domain scores for caregivers compared to survivors

\begin{tabular}{|c|c|c|c|c|c|c|c|c|c|c|}
\hline Domain & Group & $\mathrm{n}$ & Mean & SD & $\mathrm{t}$ & $\mathrm{df}$ & $\mathrm{p}$ & $\begin{array}{l}\text { Mean } \\
\text { Difference }\end{array}$ & CI lower & $\begin{array}{l}\text { CI } \\
\text { upper }\end{array}$ \\
\hline Physical Function & $\begin{array}{l}\text { Survivor } \\
\text { Carer }\end{array}$ & $\begin{array}{l}97 \\
93\end{array}$ & $\begin{array}{l}50.0 \\
69.4\end{array}$ & $\begin{array}{l}32.9 \\
30.8\end{array}$ & -4.18 & 188 & 0.012 & -19.36 & -28.49 & -10.22 \\
\hline $\begin{array}{l}\text { Role Limitations: } \\
\text { Physical }\end{array}$ & $\begin{array}{l}\text { Survivor } \\
\text { Carer }\end{array}$ & $\begin{array}{l}95 \\
91\end{array}$ & $\begin{array}{l}42.1 \\
62.8\end{array}$ & $\begin{array}{l}45.4 \\
43.0\end{array}$ & -3.19 & 184 & 0.024 & -20.72 & -33.53 & -7.90 \\
\hline $\begin{array}{l}\text { Role Limitations: } \\
\text { Emotional }\end{array}$ & $\begin{array}{l}\text { Survivor } \\
\text { Carer }\end{array}$ & $\begin{array}{l}95 \\
90\end{array}$ & $\begin{array}{l}58.4 \\
71.4\end{array}$ & $\begin{array}{l}45.5 \\
37.7\end{array}$ & -2.13 & 179 & 0.48 & -13.06 & -25.17 & -0.95 \\
\hline Mental Health & $\begin{array}{l}\text { Survivor } \\
\text { Carer }\end{array}$ & $\begin{array}{l}96 \\
91 \\
\end{array}$ & $\begin{array}{l}70.2 \\
70.3 \\
\end{array}$ & $\begin{array}{l}21.5 \\
21.3 \\
\end{array}$ & -0.04 & 185 & 0.97 & -0.13 & -6.32 & 6.05 \\
\hline Vitality & $\begin{array}{l}\text { Survivor } \\
\text { Carer }\end{array}$ & $\begin{array}{l}96 \\
91\end{array}$ & $\begin{array}{l}47.2 \\
54.8\end{array}$ & $\begin{array}{l}23.6 \\
23.4\end{array}$ & -2.20 & 185 & 0.36 & -7.60 & -14.40 & -0.80 \\
\hline $\begin{array}{ll}\text { General } & \text { Health } \\
\text { Perception } & \end{array}$ & $\begin{array}{l}\text { Survivor } \\
\text { Carer }\end{array}$ & $\begin{array}{l}96 \\
91\end{array}$ & $\begin{array}{l}50.7 \\
59.2\end{array}$ & $\begin{array}{l}24.4 \\
22.1\end{array}$ & -2.48 & 185 & 0.12 & -8.46 & -15.21 & -1.72 \\
\hline Change in Health & $\begin{array}{l}\text { Survivor } \\
\text { Carer }\end{array}$ & $\begin{array}{l}96 \\
93\end{array}$ & $\begin{array}{l}52.6 \\
44.6\end{array}$ & $\begin{array}{l}25.7 \\
17.2\end{array}$ & 2.51 & 166 & 0.12 & 7.98 & 1.70 & 14.26 \\
\hline Pain & $\begin{array}{l}\text { Survivor } \\
\text { Carer }\end{array}$ & $\begin{array}{l}97 \\
91\end{array}$ & $\begin{array}{l}62.7 \\
69.4\end{array}$ & $\begin{array}{l}30.3 \\
27.6\end{array}$ & -1.57 & 186 & 0.12 & -6.68 & -15.05 & 1.69 \\
\hline Social Functioning & $\begin{array}{l}\text { Survivor } \\
\text { Carer }\end{array}$ & $\begin{array}{l}97 \\
91 \\
\end{array}$ & $\begin{array}{l}63.3 \\
77.4 \\
\end{array}$ & $\begin{array}{l}27.2 \\
26.5 \\
\end{array}$ & -1.05 & 186 & 0.29 & -4.14 & -11.89 & 3.61 \\
\hline $\begin{array}{l}\text { Physical } \\
\text { Component Score }\end{array}$ & $\begin{array}{l}\text { Survivor } \\
\text { Carer }\end{array}$ & $\begin{array}{l}94 \\
88\end{array}$ & $\begin{array}{l}35.5 \\
44.3\end{array}$ & $\begin{array}{l}18.9 \\
17.3\end{array}$ & -3.28 & 180 & 0.012 & -8.82 & -14.13 & -3.51 \\
\hline $\begin{array}{l}\text { Mental Component } \\
\text { Score }\end{array}$ & $\begin{array}{l}\text { Survivor } \\
\text { Carer }\end{array}$ & $\begin{array}{l}94 \\
88\end{array}$ & $\begin{array}{l}45.8 \\
45.7\end{array}$ & $\begin{array}{l}12.7 \\
12.0\end{array}$ & 0.01 & 180 & 0.99 & 0.02 & -3.62 & 3.65 \\
\hline Number of illnesses & $\begin{array}{l}\text { Survivor } \\
\text { Carer }\end{array}$ & $\begin{array}{l}97 \\
96 \\
\end{array}$ & $\begin{array}{l}1.9 \\
1.2 \\
\end{array}$ & $\begin{array}{l}1.6 \\
1.3\end{array}$ & 3.12 & 191 & 0.012 & 0.69 & 0.25 & 1.12 \\
\hline
\end{tabular}

*T-Tests and Bonferroni adjusted; higher scores denote better health 
Table 3: Multiple linear regression exploring the association between cancer caregiver characteristics and (i) physical health and (ii) mental health component summary scores

\begin{tabular}{|c|c|c|c|c|c|}
\hline Variable & $\mathrm{N}$ & $\begin{array}{l}\text { Mean } \\
\text { Physical } \\
\text { comp } \\
\text { score }\end{array}$ & $\begin{array}{l}\text { ** Fully adjusted mean } \\
(95 \% \text { CI) p value }\end{array}$ & $\begin{array}{l}\text { Mean } \\
\text { mental } \\
\text { comp score }\end{array}$ & $\begin{array}{l}\text { ** Fully adjusted mean } \\
(95 \% \mathrm{CI}) \text { p value }\end{array}$ \\
\hline Age & 80 & 44.1 & $-0.25(-0.7,0.2) \mathrm{p}=0.25$ & 45.8 & $0.30(-0.1,0.7) \mathrm{p}=0.17$ \\
\hline Sex & $\begin{array}{l}\text { Male (32) } \\
\text { Female (57) }\end{array}$ & $\begin{array}{l}47.2 \\
42.9\end{array}$ & $\begin{array}{l}\mathrm{p}=0.90 \\
0.62(-9.8,11.0)\end{array}$ & $\begin{array}{l}49.0 \\
44.0\end{array}$ & $\begin{array}{l}\mathrm{p}=0.91 \\
-0.6(-9.9,11.1)\end{array}$ \\
\hline Cancer site & $\begin{array}{l}\text { Melanoma(3) } \\
\text { Breast (29) } \\
\text { Colorectal (10) } \\
\text { Gynaecological } \\
\text { (4) } \\
\text { Head and Neck } \\
\text { (6) } \\
\text { Haematological } \\
\text { (8) } \\
\text { Prostate (21) }\end{array}$ & $\begin{array}{l}40.2 \\
48.7 \\
35.5 \\
39.2 \\
\\
41.4 \\
43.8 \\
\end{array}$ & $\begin{array}{l}\mathrm{p}=0.19 \\
25.3(-4.9,55.4) \\
22.3(-8.4,53.0) \\
0.66(-37.0,38.3) \\
27.3(-10.0,64.6) \\
26.4(-3.8,56.7) \\
\\
20.2(-10.8,15.3)\end{array}$ & $\begin{array}{l}38.6 \\
47.7 \\
45.4 \\
46.9 \\
\\
45.7 \\
\\
44.9 \\
\end{array}$ & $\begin{array}{l}\mathrm{p}=0.92 \\
14.7(-15.8,45.1) \\
15.9(-15.1,47.0) \\
16.5(-21.5,54.5) \\
10.8(-26.9,48.5) \\
16.8(-13.7,47.3) \\
11.7(-19.7,43.0)\end{array}$ \\
\hline $\begin{array}{l}\text { Years since } \\
\text { diagnosis }\end{array}$ & $\begin{array}{l}20+(3) \\
1-3(33) \\
4-6(22) \\
7-9(12) \\
9-11(14) \\
12-15(4) \\
16-20(1)\end{array}$ & $\begin{array}{l}36.7 \\
45.2 \\
43.5 \\
43.9 \\
43.1 \\
51.8 \\
62.6\end{array}$ & $\begin{array}{l}\mathrm{p}=0.84 \\
3.1(-19.3,25.5) \\
-2.8(-24.8,19.2) \\
-5.0(-27.7,17.8) \\
-2.5(-29.5,24.6) \\
-0.4(-28.2,27.4)\end{array}$ & $\begin{array}{l}43.7 \\
45.5 \\
47.4 \\
43.1 \\
43.8 \\
53.5 \\
57.7\end{array}$ & $\begin{array}{l}\mathrm{p}=0.98 \\
0.99(-21.6,23.6) \\
2.9(-19.4,25.1) \\
-1.7(-24.6,21.3) \\
1.6(-25.7,28.9) \\
5.0(-23.1,33.1)\end{array}$ \\
\hline $\mathrm{HSU}$ & 86 & 44.1 & $-0.23(-0.5,0.7) \mathrm{p}=0.13$ & 45.6 & $\begin{array}{l}-0.30(-0.60,-0.01) \\
p=0.04\end{array}$ \\
\hline Illnesses & 89 & 44.5 & $\begin{array}{l}-5.3(-8.9,-1.7) \\
p=0.05\end{array}$ & 45.8 & $-0.3(-3.9,3.4) p=0.88$ \\
\hline $\begin{array}{l}\text { Hours per } \\
\text { week spent } \\
\text { caring }\end{array}$ & $\begin{array}{l}22+(14) \\
1-7(8) \\
8-14(4) \\
15-21(22)\end{array}$ & $\begin{array}{l}53.2 \\
40.6 \\
43.1 \\
33.7\end{array}$ & $\begin{array}{l}\mathrm{p}=0.09 \\
-2.5(-19.4,14.5) \\
-7.3(-23.4,8.9) \\
-14.2(-25.5,-2.9)\end{array}$ & $\begin{array}{l}46.4 \\
43.9 \\
44.5 \\
40.5\end{array}$ & $\begin{array}{l}\mathrm{p}=0.22 \\
11.6(0.2,23.0) \\
9.7(-7.1,26.5) \\
7.1(-9.0,23.1)\end{array}$ \\
\hline
\end{tabular}


Table 4: Health service use by survivors and caregivers

\begin{tabular}{|l|l|l|l|l|}
\hline Health Service & Group & Mean no of visits & U & P \\
\hline GP & Caregiver & 3.24 & 3642.00 & 0.08 \\
& Survivor & 4.26 & & \\
\hline Primary Care & Caregiver & 1.80 & 3565.50 & 0.02 \\
Professional & Survivor & 3.04 & 4598.50 & 0.48 \\
\hline Mental Health & Caregiver & 0.28 & & \\
Professional & Survivor & 0.07 & 4367.00 & 0.20 \\
\hline Allied Health & Caregiver & 0.75 & & \\
Professional & Survivor & 0.65 & 4349.00 & 0.13 \\
\hline Hospital Stay & Caregiver & 0.60 & 2360.00 & 0.008 \\
& Survivor & 0.89 & & \\
\hline Outpatient & Caregiver & 0.88 & 4664.00 & 0.85 \\
& Survivor & 3.1 & & \\
\hline Complementary or & Caregiver & 1.20 & 4557.50 & 0.35 \\
Alternative & Survivor & 0.58 & & \\
Medicine & & & & \\
\hline District Nurse & Caregiver & 0.15 & & \\
& Survivor & 0.29 & & \\
\hline
\end{tabular}

*Mann-Whitney test and Bonferonni Adjusted 